\title{
Recognition and enforcement of foreign judgments in the Law of Iran and England: a comparative study
}

\author{
Abasat Pour Mohammad ${ }^{1}$ and Ahmad Aminnasab ${ }^{2}$ \\ 1 Corresponding Author: Assistant Professor, Department of Law, Maragheh Branch, Islamic Azad University, Maragheh, Iran. E-mail: \\ dr_a_p20@yahoo.com \\ 2 PhD Student, Department of Law, Maragheh Branch, Islamic Azad University, Maragheh, Iran.
}

\begin{abstract}
The aim of this study was to Recognition and Enforcement of Foreign Judgments in the Law of Iran and England: A Comparative Study. There are a lot of similarities and commonalities between the legal system of Iran and England in the field of recognition and enforcement of the foreign judgments including public discipline and conflicting judgments. Public discipline in England Law is more specific than that of Iran. Being a civil case of the judgment, impossibility of recognition, enforcement of tax and criminal judgments are among the similarities of the two systems. On the other hand, reciprocity, precise of the foreign court, and the jurisdiction governing the nature of the claim are among instances which are different in Iran and England legal systems on the recognizing of the enforcement of foreign judgments.
\end{abstract}

Keywords: Recognition, foreign judgments, legal system of Iran, legal system of England.

\section{INTRODUCTION}

In the present age which is called the communication age, dialogue among civilizations and information explosion, migration and business have taken a new meaning and social communication facilities have made easier and more feasible (HAYATI, 2011). The Private International Law also has been changed and expanded increasingly; so, countries will have less authority and in fact the world goes forward the Legal Unity System. Although the law of civil judgment enforcement has envisaged the recognition and enforcement of foreign judgments and its provisions seem suitable somewhat in terms of justice principles, it must be understood that a written law in order to enforce the foreign judgments is not enough solely but the jurisprudence and legal doctrine that are the result of law enforcement over time have a valuable role in its enforcement and can compensate some of its weaknesses and shortcomings. What drew attention mostly is the partnership that the jurisprudence of the countries having in fulfillment and expansion of the law associated with enforcement of foreign judgments (PARHISI, 2010).

\section{JUDGEMENT OF FOREIGN COURTS}

Fraud Even if the issued decrees by a foreign court were final decisions and all the terms were gathered in them, they would applicable just in the territorial jurisdiction of the same country because" the issued decrees by a country are issued under the territorial of that country and according to the principles of the General International 
Law the sovereignty right of any country limits to its political territory and no government can sovereign power out of its own territory (REZAEI, 2002). Two important issues in the Private International Law merit mentioning in discussing the judgments of the foreign courts: 1 . Recognition of a foreign judgment in which "a court of a country would asked to consider valid the judgment issued by the foreign jurisdiction. Therefore, the aim of recognition the foreign judgment isn't the direct enforce of any judgment issued by a foreign court but is to accept and validate it."

\section{CLOSER INVESTIGATION OF THE RECOGNITION OF FOREIGN JUDGE-MENTS}

Judgment which means that "a court of a country is asked to treat with the judgments issued in a foreign court as the judgments issued in interior courts and to issue their enforcement."

It must be noted that the enforcement phase of a foreign judgment is done following its recognition, and a court in a country shall recognize a judgment before enforcement yet enforcement isn't necessary following recognition. The article 975 of civil code Iran states in this regard "the court shall not enforce those foreign rules or private agreements which are against the public ethics or against public peace due to hurt the feelings of society or other reasons though enforcement of such rules are allowed essentially" (MADANI, 2014).

The public peace is "the rules that the purpose of codifying them is to protect public interests, and to violate them disrupt the order which is necessary to true administrative, political, economical process or to protect the family." The comparative study of the legal systems of Iran and England on principles, terms, and restraints of recognition and enforcement of the foreign judgments in the Territories of the two countries clears the inevitable fact that recognition and enforcement of the foreign judgments have an especial place and importance among different issues of the Private International law.

In the present age which is called the communication age, dialogue among civilizations and information explosion, migration and business have taken a new meaning and social communication facilities have made easier and more feasible. The Private International Law also has been changed and expanded increasingly; so, countries will have less authority and in fact the world goes forward the Legal Unity System. Although the law of civil judgment enforcement adopted in 1977 has envisaged the recognition and enforcement of foreign judgments and its provisions seem suitable somewhat in terms of justice principles, it must be understood that a written law in order to enforce the foreign judgments is not enough solely but the jurisprudence and legal doctrine that are the result of law enforcement over time have a valuable role in its enforcement and can compensate some of its weaknesses and shortcomings. What drew attention mostly is the partnership that the jurisprudence of the countries having in fulfillment and expansion of the law associated with enforcement of foreign judgments. If the countries want to achieve success on International Trading, Fundraising, and even membership in World Trading Organization (WHO), they shall close their current judicial system to the level of International Standards. Anyway, today the recognition of some of issued de- 
crees such as the judgments associated to the situation and competency of subjects by the foreign courts have become as inevitable facts of the International life, therefore perceiving the necessity of the issue most countries have attempted to provide the possibility of recognition and enforcement of the foreign judgments in their own territory via codifying rules and laws or via creating and establishing the jurisprudence (MOSCHTAGHI, 2010).

Of course, this doesn't mean that the countries are required to recognize and enforce the foreign judgments absolutely, but the aim is to provide the possibility of enforcement of the foreign civil judgments considering some conditions. Thus, the issue of recognition and validity of the acquired rights of subjects will be considered and more expansion on Private International law will be occurred (ALMASI, 1995).

There is no doubt upon incapability of enforcement of the Foreign Criminal Judgments in Iran. The rules of the Islamic Republic of Iran is silent about the enforcement of the criminal judgments of the foreign countries and since the principle is on the lack of enforcement of the foreign criminal judgments, and some reasons are needed for enforcement authority, therefore, the Iranian judicial authorities aren't allowed to enforce the alien criminal judgments. Legal department of the judiciary opined (10/11/1994) on the foreign criminal judgments that:" enforcement of the criminal judgments of the other countries about Iranian subjects has no legal authority... how can pledge to enforce the criminal judgment of the foreign country about a person without possessing crime of an Iranian citizen by the judiciary courts of Iran" (ALMASI, 1995, p 6).
The interior judge shall command that the foreign judgment if enforceable. According to law, as about the interior judgments that a precipe shall be issued upon the order of the court, the foreign judgments are enforced upon the order of judge. By this way the sovereignty of the state and authority of the judiciary will be kept "because the order which is issued to the formal authorities in order to enforce is on the basis of the foreign written judgment but it is the result of the interior judge's decision and the judge isn't bound for the foreign judgment" (ALMASI, 2004).

\section{THE COMPARATIVE STUDY DETAILS}

In the present comparative study it is observed that an individual applying the recognition and enforcement of the foreign judgments in Iran can, in case of excising the necessary terms and lack of the restraints counting in the Article 169 of the enforcement law of the foreign judgments, can achieve the purpose without requiring preference via petition a suit. According to Common Law in England the demandant of recognition can bring a new action on the basis of the main reason of claim of the foreign judgment in England or the individual can bring an action based on the foreign judgment as an independent reason but there are some exceptions about this rule by positive laws which are applied on issued judgments in specific geographic area; of course, the issued judgment in some countries are recognized and enforced yet according to the Common Law of England (KHALEGHI, 2012).

The legal policy of Iran on the subject of the study is based on reciprocal behavior and the issued judgments of those coun- 
tries that have reciprocal action about the issued judgments of the courts of Iran are enforceable in Iran. "Obligation" Doctrine in England is applied and put forward as the basis of current legal policy of England that according to above-mentioned descriptions the Doctrine causes widely recognition and enforcement of the foreign judgments in the territory of the country (KATOUZIAN, 2010).

Common and similar conditions of the two legal systems to recognize and enforce the foreign judgments the following items can be pointed out:

1. Competency of the court issued the judgment considering the regulations of the Private International Law of the country in which the recognition and enforcement is done. It is evident that the foreign court may be envisaged competent due to some conflicts and differences but the same court may be recognized incompetent at the same case in the legal system of Iran.

2. Absoluteness of the judgment. The two legal systems set the interpret of the court issued the judgment as standard and criterion according to the concept of certainty.

3. Civilizing of the subject of judgment.

4. Impossibility of the recognition and enforcement of the tax and criminal judgments. In this regard the two legal systems have envisaged possible and permissible the enforcement of judgments on the relief of a private claimant issued in criminal judgments in their own territory.

\section{DIFFERENCES OF THE TWO LEGAL SYSTEMS}

Large Differences of the two legal systems to recognize and enforce the foreign judgments the following items can be pointed out:

1. Reciprocal behavior: the courts of Iran are not permitted to order the enforcement of the foreign judgment; moreover, the accepted theoretical basis of the legal system of Iran is also the reciprocal behavior whereas today the reciprocal behavior is not proffered as a requisition in England as mentioned before.

2. Issuing the enforcement order by the foreign court: this term has been envisaged in the law of Iran but it isn't needed in England according to the rules of the Common Law.

3. Competency of the law governing the nature of the claim: in the legal system of Iran the investigation of the competency of the law governing the nature of the claim by the court of Iran is necessary as the court of the location of the recognition and enforcement in order to issue the order of enforcement, but in legal system of England the investigation of the competency of the law governing the nature of the claim is not needed upon ascertaining of competence of the foreign court (MADANI, 2013).

\section{CONCLUSION}

There are a lot of similarities and commonalities between the legal system of both countries in the field of recognition and enforcement of the foreign judgments including public discipline and conflicting judgments. It should be noted that the concept of the public peace in the law of Iran includes the cases such as fraud and violation of the concept of natural justice which have been envisaged as independent restraints in England law. In other word, the concept of public peace in England law is 
more specific than that of Iran. Although, a number of limitations about enforcement of foreign judgments has been resolved and obviated by bilateral or multilateral contracts on mutual law enforcement among countries, it seems that there should be a long way for creating common and universal rules.

It is hoped that the gap between the two legal systems to be lessen by the better perception of an international life necessities and the need of the international society to the necessity of the recognition and validation of the acquired rights. It is necessary to mention that before the Islamic revolution of Iran the enforcement of the foreign judgments were not limited and the openness of the borders of the most foreign countries to Iranian nationals as well as travelling the foreigners to Iran had raised the enforcement of most of the foreign judgments in Iran, but it has been limited after the Islamic Revolution of Iran. Therefore, considering the particular situation of Iran in addition to the imposed war for a relatively long time as well as the problems resulted of the war, economic blockade, the arrogant plans of the great governments, and so on are considered the reasons of this limitation. Accordingly, the level of enforcement of the foreign judgments in Iran is declined to the rare cases but in Iran like other countries, only the laws associated to the enforcement of the foreign judgments are peculiar to the laws associated to the ninth chapter of the law of the enforcement of civil judgments which have been approved in the past time and don't meet the legal needs of today evolved society. Furthermore, considering the enormous volume of rules and regulations of the foreign countries in this area which are emended and changed every day our current regulations have no consistency and proportionality with the internal evolutions and the society needs; therefore, it is suggested to amend the reciprocal theory to Obligation, Legal Duty, and/or Acquired rights in order to remove this legal shortcoming, achieve the international standards, and meet the needs of today society in accordance with the international evolutions. Additionally, since insignificant research has been conducted on the enforcement of the foreign judgments and the public have less access to the updated foreign references in the libraries and scientific centers, it is suggested to do more researches at this area in Iran and to provide the updated foreign references which present the latest legal evolutions, changes, research, and doctrine to obviate partially the legal shortcomings and gaps.

\section{REFERENCES}

ALMASI, NEJAD A. Conflict of Laws, Tehran University Publications, 2004, pp. 212-218. ALMASI, NEJAD A. Recognition and Enforcement of Foreign Judgments, Journal of Tehran Faculty of Law and Political Science, 1995, Vol. 10, no.3, pp.6-11.

HAYATI, ALI A. Enforcement of Civil Judgments in the Current Legal Order, Mizan Publications, 2011, pp. 106-109.

KATOUZIAN, N. Civil Law Legal System Today, Dadgostar Publications, 2010, pp.102103.

KHALEGHI, A. Transferring Convicts, Journal of the Faculty of Law and Political Sciences of Tehran University, Vol. 10, no.3, 2012, pp.12,19.

MADANI, J. Private International Law, Ganj Danesh, 2013, pp. 96-102. 
MADANI, J. Private International Law, Ganje-Danesh, 2014, pp. 221-222.

MOSCHTAGHI, R. Die menschenrechtli-che Situation sunnitischer Kurden in der Islamischen Republik Iran, Mizan Publications, 2010, p. 66-74.

PARHISI, P. Frauen in der iranischen Verfassungsordnung, Majd Publications, 2010, p. 31-39.

REZAEI, H. "The Iranian Criminal Justice under the Islamization Projec," European Journal of Crime, Criminal Law and Criminal Justice, 2002, Vol. 10, no 1, pp. 4-5.

License information: This is an openaccess article distributed under the terms of the Creative Commons Attribution License, which permits unrestricted use, distribution, and reproduction in any medium, provided the original work is properly cited.

Article received on June 09, 2017.

Evaluated July 04, 2017.

Accepted on Jully 04, 2017.

Published on August 18, 2017.

How cite this article (ABNT):

MOHAMMAD, Abasat Pour; AMINNASAB, Ahmad. Recognition and enforcement of foreign judgments in the Law of Iran and England: a comparative study. Estação Científica (UNIFAP), Macapá, v. 7, n. 1, p. 71-76, jan./abr. 2017. 